\title{
The Influence of Prey Availability and Vegetation Characteristics on Scent Station Visitation Rates of Coyotes, Canis latrans, in a Heterogeneous Environment
}

\author{
LYNDA A. RANDA ${ }^{1}$ and JOHN A. YungeR ${ }^{2}$
}

Department of Biological Sciences, Northern Illinois University, DeKalb, Illinois 60115 USA

${ }^{1}$ Present address: Natural and Applied Sciences Division, College of DuPage, 425 Fawell Boulevard, Glen Ellyn, Illinois 60137 USA

${ }^{2}$ Present address: Environmental Biology Program, Governors State University, University Park, Illinois 60466 USA

Randa, Lynda A., and John A. Yunger. 2004. The influence of prey availability and vegetation characteristics on scent station visitation rates of Coyotes, Canis latrans, in a heterogeneous environment. Canadian Field-Naturalist 118(3): 341-353.

We investigated the effects of local prey fluctuations and habitat variables on the scent station visitation rates of the Coyote (Canis latrans) in northern Illinois within a heterogeneous environment. Availability of small mammalian prey was assessed by monthly mark-recapture sampling and visual counts conducted along three, 192-m transects in each of seven habitats that ranged from grassland to wooded sites. Habitat metrics, which included foliage density, ground cover, and canopy cover, were also collected for the same seven habitats. Visitation rates of Coyotes were determined from scent station lines parallel to the small mammal trapping transects. A multiple regression analysis indicated that Coyote visitation rates across the study site were influenced positively by vole (Microtus spp.) abundance and negatively by canopy cover. When Coyote visitation rates were regressed on vole abundance for only the habitats in which voles occurred, the relationship was not significant. This may be attributed to the general avoidance of wooded areas by Coyotes. Coyotes did, however, respond to experimentallyinduced abundant patches of Peromyscus. These findings suggest Coyotes selectively use grassland habitats within a heterogeneous environment and may modify their use according to prey availability.

Key Words: Coyote, Canis latrans, habitat use, heterogeneous environment, prey availability, scent station, Illinois.

The Coyote, Canis latrans, is among the most adaptable of North American predators. Across an expansive range, the species occupies a variety of habitats and consumes a diversity of foods (Bekoff 1978). As such, the Coyote has been the focus of various local and regional studies of distribution, activity patterns, and diet selection. In particular, spatial and temporal activity patterns have been explicitly described (e.g., Andelt and Gipson 1979; Holzman et al. 1992), yet there has often been only circumstantial evidence as to causal factors (e.g., Person and Hirth 1991). Understanding potential determinants of Coyote spatial distribution and activity patterns requires an understanding of factors such as diet composition and specific use of available habitat types.

Predators exhibiting flexible behavior patterns, such as Coyotes, provide an opportunity for studying possible rapid responses to prey availability. Previous studies have shown that diets (Andelt et al. 1987; Brillhart and Kaufman 1995; Todd et al. 1981) and temporal activities of Coyotes (Shivik and Crabtree 1995) can vary seasonally based upon prey availability. Because space use and movements of vertebrate predators are closely coupled to foraging behavior, Coyotes could also alter their spatial use patterns in response to changes in prey availability. However, vertebrate predators frequently move over large spatial scales, whereas their smaller prey tend to be restricted to specific habitats or patches within a habitat. The study of prey in only one or a limited number of locations used by the predators (Hamlin et al. 1984; Jaksic et al. 1993; Korschgen and Stuart 1972) may preclude accurate inferences on the foraging behavior of vertebrate predators. Thus, it is important to relate predator foraging behavior among habitats to prey abundances within habitats of heterogeneous landscapes (Dunk and Cooper 1994; Korpimäki 1994).

In addition to prey, variations in vegetation structure, such as foliage density and height, among different habitats can also influence the movements and activities of vertebrate predators (Clark et al. 1993; Lamberson et al. 1994), especially in fragmented landscapes. Habitat differences may constrain predator foraging in certain areas through predators selectively using or avoiding particular habitat types (DeJong 1995; Smallwood 1995). As a result, predators may not respond to changes in prey availability within certain habitats. However, vegetation measures used to quantify predator habitat use may also be related to or reflect prey usage (Anthony et al. 1981). Such inter-relatedness must be considered when making inferences of predator behavior.

We investigated the relationships of spatial and temporal distribution of prey and vegetation characteristics to the habitat visitation of Coyotes across a heterogeneous environment. We incorporated experimental manipulations of habitat and prey, along with natural perturbations, to elicit predator behavioral responses 
within a relatively short time scale. Data collected on prey abundance and habitat variables were used to address whether scent station visitation rates of Coyotes vary among habitats and within a particular habitat in response to changes in prey availability.

\section{Study Areas}

The study site was located in northern Illinois at Fermi National Accelerator Laboratory (Fermilab) in Batavia, Illinois $\left(41^{\circ} 50^{\prime} \mathrm{N}, 88^{\circ} 15^{\prime} \mathrm{W}\right)$. Fermilab encompasses approximately 3200 ha and is characterized as a heterogeneous area, marked by distinct habitat boundaries. The areas surrounding Fermilab consisted of small open spaces of mainly agricultural land interspersed with light industry and residential neighborhoods, providing potential predator access into or out of the study site. The study was conducted at seven different locations within Fermilab, representing five habitat types: (1) oldfield, dominated by Queen Anne's Lace (Daucus carota) and Tall Goldenrod, (2) tallgrass prairie, dominated by Big Bluestem (Andropogon gerardii) and Indian Grass (Sorgastrum nutans); (3) brome grass field, dominated by Smooth Brome (Bromus inermis); (4) shrubby oldfield, a heterogeneous mix of dense shrubs and shrub-grassland mixture dominated by Tall Goldenrod (Solidago altissima) and Gray Dogwood (Cornus racemosa) with small stands of Trembling Aspen (Populus tremuloides); and (5) oak woodland, dominated by mature oaks (Quercus spp.), one woodland (Oak Woods I) characterized by less dense canopy (primarily $Q$. macrocarpa and $Q$. rubra) than the other (Oak Woods II; predominantly Q. alba and Q. rubra; Figure 1). These different habitats were chosen because they represented the heterogeneity of the study site and included all prey species potentially found in Coyote diets at Fermilab. A concurrent investigation indicated that three prey, voles (primarily Meadow Voles, Microtus pennsylvanicus, and rarely Prairie Voles, M. ochrogaster), Eastern Cottontails (Sylvilagus floridanus), and mice (Peromyscus spp.), constituted $39.4 \%, 31.3 \%$, and $8.4 \%$ of the Coyote diets, respectively, which was at least two times greater than the proportion of any other prey item (Randa 1996).

\section{Methods \\ Availability of prey}

From March 1994 through May 1995, small mammal species compositions and abundances were estimated by mark-recapture live-trapping on three, $192 \mathrm{~m}$ transects located within each of the seven habitats (Figure 1). The transects were parallel and spaced from 70 to $85 \mathrm{~m}$ to help maximize their independence in relation to small mammal movements. At least $50 \mathrm{~m}$ was maintained from each transect to habitat boundaries to avoid edge effects. Seventeen trap stations were spaced at 12-m intervals along each transect, totaling 51 trap stations per habitat. One $23 \times 9 \times 7.5 \mathrm{~cm}$
Sherman live-trap, baited with a peanut butter and oats mixture, was placed at each station. All habitats were trapped for two nights on a monthly basis. Traps were checked early morning and late afternoon (ca. every $12 \mathrm{hr}$ ). Captured individuals were marked with a uniquely numbered eartag (Monel Number 1, National Band and Tag Co., Newport, Kentucky).

Nocturnal visual counts, using a high-powered spotlight (Woolf et al. 1993), were conducted for Eastern Cottontails in each of the seven habitats. The counts were conducted twice during each of the 15 small mammal trap sessions by sighting with binoculars, at one end and midway, along the small mammal trapping transects. Animals within ca. $25 \mathrm{~m}$ of the transect were counted. For the visual counts, the trapping transects were lengthened to $250 \mathrm{~m}$, delineated by flagging at opposing ends, to allow for the larger spatial movements of rabbits. Care was taken not to double count animals potentially moving between transects.

For the experimental studies, fire was used as a means of manipulating prey. Tallgrass Prairie I was burned between the October and November 1994 small mammal surveys, a period of time when small mammal abundances peak in northern Illinois (Yunger 2002). This site was adjacent to Oak Woods I (Figure 1), which concurrently experienced a high acorn production year. Both habitats contained two closely related species of small mammals (Peromyscus maniculatus, the Deer Mouse, in the prairie and P. leucopus, the White-footed Mouse, in the woods), which were similar in body size and morphology. Numerical responses, caused by immigration of Deer Mice to prairie burns, have been documented previously (Cook 1959; Kaufman et al. 1983, 1988). Similarly, acorns have been shown to be an important local food source for mice (Peromyscus spp: Ostfeld et al. 1996; Wolff 1996). Consequently, we predicted a localized increase of P. maniculatus in Tallgrass Prairie I and P. leucopus in Oakwoods I. The proximity of these two habitats provided the opportunity to compare changes in Coyote habitat visitation following the manipulations of prey abundance.

Prey also was manipulated in Tallgrass Prairie II through food supplementation. From October 1994 through March 1995, $10 \mathrm{~kg}$ of commercial rodent chow was hand broadcasted at weekly intervals on two of four (i.e., two treatment and two control), 0.60-ha square plots. As part of a separate study on the population dynamics of small mammals (Yunger 2002), prey numbers were determined by monthly trapping on a $6 \times 6$ grid with $12-\mathrm{m}$ spacing in each plot. Predator spatial and temporal visitation responses to resulting changes in prey due to the food supplementation experiment were also compared to the natural increase in acorns of Oak Woods I and to the prey response to experimental burning of Tallgrass Prairie I.

Visitation rates of Coyotes 


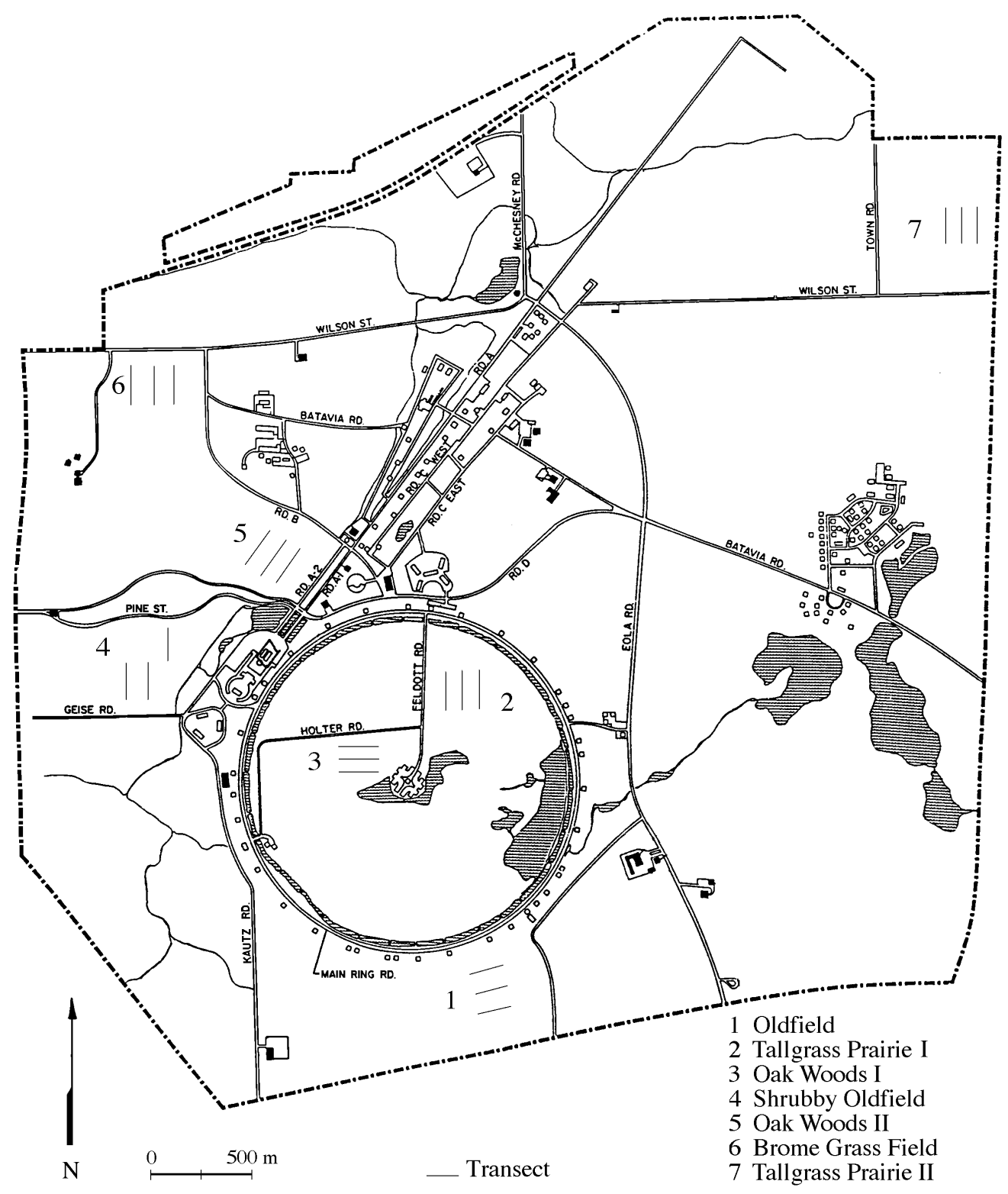

FIGURE 1. Map of Fermilab showing the seven different study locations (habitats) and approximate locations of scent station transects in each habitat. Dashed line represents boundary of Fermilab. Roads, buildings, and open water (dark shaded areas) are included to further depict heterogeneity of the study site. 
Coyote visitation rates were monitored through the use of scent stations. These were constructed by excavating a $50-\mathrm{cm}$ diameter by $10-\mathrm{cm}$ deep circular depression, rimmed up to the ground surface with a $10-\mathrm{cm}$ wide strip of aluminum flashing to inhibit invasive growth from surrounding vegetation, and filled with fine-grained sand. The resulting stations were level with the ground surface and fairly inconspicuous except for the lack of vegetation. Scent stations were located along 175-m transects, parallel to the small mammal trapping transects, in each of the seven locations. Transects were spaced ca. $100 \mathrm{~m}$ apart while maintaining at least $50 \mathrm{~m}$ from a transect to the habitat edge. Eight scent stations were spaced every $25 \mathrm{~m}$ along each transect in the seven habitats, for a total of 24 scent stations per location. At the start of each monitoring period, all scent stations were baited by placing a cotton swab dipped in a liquid commercial predator lure (Cronk's Predator 500, Wisscasset, Maine) upright in the middle of the scent station and the sand was smoothed. Stations were simultaneously monitored for a minimum of 2 nights (without precipitation), 1 to 3 times monthly (mean of 2.1 times per month); sand was not smoothed or otherwise disturbed by the authors during each monitoring period. Monthly scent station use was calculated for each habitat based upon visitation rates, or the proportion of scent stations exhibiting Coyote tracks in a given habitat, and divided by the total number of operative nights to account for any variation in sampling duration.

Within-habitat Coyote visitation rates were evaluated through the small mammal food supplementation experiment conducted in Tallgrass Prairie II. In January 1995, one scent station was placed at each corner of the four plots previously described for this habitat. These 16 stations were monitored from February 1995 through May 1995 to compare scent station visitation rates of Coyotes to prey numbers in supplemented and non-supplemented plots.

\section{Vegetation analysis}

Vertical foliage density, percent ground cover, and canopy cover were used to describe habitat structure for each of the seven habitats. Vegetation measurements were collected at 24 stations per habitat, along alternating stations of the small mammal trapping transects. Foliage density was measured using a modified profile board technique (MacArthur and MacArthur 1961). Percent cover of three, $30 \times 50-\mathrm{cm}$ profile boards, divided into $15,10 \times 10-\mathrm{cm}$ cells, was measured at $0.5 \mathrm{~m}, 1.0 \mathrm{~m}$ and $1.5 \mathrm{~m}$ from ground to mid-level of the board. A cell was considered covered if $50 \%$ or more of the cell, viewed from a 5-m distance, was obstructed by vegetation. The proportion of cells covered determined percent cover of an individual board. All readings were taken facing north and there was no apparent patterning or trending in vegetation structure and diversity among each of the four cardinal directions. To arrive at a single foliage density value for each habitat, the proportion of vegetation cover was averaged across the three vertical profile boards for each sampling station, then the mean of the resulting 24 values was calculated.

Percent ground cover was assessed at each sampling station by the amount of vegetation (herbaceous, woody, and leaf litter) occupying a $1-\mathrm{m}^{2}$ quadrat against visible patches of ground (Brower et al. 1990). Canopy cover was estimated by the presence or absence (scored as 1 or 0 , respectively) of vegetation viewed through a vertical ocular tube (James and Shugart 1970) at each sampling station. Average ground cover and canopy cover for each habitat was obtained by taking the mean of the 24 values of each metric.

The vegetation analysis was conducted once in March 1994 and once in August 1994, representing vegetation structure characteristic of the non-growing and growing seasons, respectively. Two months of the year, May and November, represent transitions between the growing and non-growing seasons and hence, characteristic vegetation density. For this study, vegetation variables for May were described by the August survey (i.e., high foliage density), and vegetation variables for November were described by the March survey (i.e., low foliage density).

\section{Data analysis}

Analyses of small mammal prey were based upon minimum number known alive (MNKA). This estimate was generated for each individual transect per month using Package C. M. R. (Le Boulengé 1987). The estimates then were averaged for the three transects to yield monthly small mammal species composition and abundance for each habitat.

To examine whether Coyotes shifted visitation rates in response to prey, it was necessary to determine whether spatial and temporal differences in prey abundances existed. Analysis of covariance (ANCOVA), conducted with SAS PROC GLM (SAS Institute Inc. 1990), was used to compare abundances of the most important prey species identified in Fermilab Coyote diets (Randa 1996). Specifically, analyses were conducted to test for significant fluctuations in prey abundances over time among each of the seven habitats. ANCOVA can be used to test for an interaction or heterogeneity of slopes (Littell et al. 1991) and was chosen because sampling units (i.e., habitats) were not replicated in space. Temporal changes of prey populations were indicated by crossing the categorical variable (i.e., prey abundances across habitats or prey abundances per habitat) with the continuous covariate (time). Traditional model building techniques were used (Box et al. 1978) in which non-significant, higherorder interactions were removed from the model. If no significant sources of variation were detected, the full model was reported. If significant interaction of variables occurred (i.e., heterogeneity of slopes), significance of main effects were inferred from the plotted data. Statistical inferences were based on type III 
sum-of-squares and significance accepted at a $=0.05$.

Multiple regression (SAS PROC REG; SAS Institute Inc. 1990) was used to evaluate the effect prey availability and vegetation structure had on Coyote visitation rates. Six independent variables were used in the model: the abundances of the three main prey genera, (1) Microtus, (2) Peromyscus, and (3) Sylvilagus, and the three vegetation variables, (4) vertical foliage density, (5) percent ground cover, and (6) canopy cover. Each observation in the multiple regression represented a single measure of the independent variable in one of the seven habitats during one of 15 months. Thus, there were 105 observations for each independent variable, or a total of 630 data points for the regression analysis. Data were logarithmic-transformed prior to analysis to help satisfy assumption of normality of the residuals. Collinearity diagnostics, such as tolerance values and variance inflation factors, indicated a lack of colinearity between the regressors, hence all independent variables were retained in the model.

Simple linear regression, performed with SAS PROC REG (SAS Institute Inc. 1990), was used to compare Coyote visitation rates against mice abundances in each of the two adjacent habitats, Tallgrass Prairie I and Oak Woods I. We performed a separate analysis for the response of Coyotes to prey increase following manipulation of the prey's food supply. Visitation rates of Coyotes around the experimental plots in Tallgrass Prairie II were analyzed using a one-way repeated measures analysis of variance (rmANOVA), with SAS PROC GLM (SAS Institute Inc. 1990). Inferences were based on Huynh-Feldt adjusted $P$-values for the rmANOVA.

\section{Results}

\section{Among-habitat prey fluctuations}

There was variation in spatial-temporal abundances of prey species (Figure 2) with significant species $\left(R^{2}=0.658, F_{[2,264]}=6.21, P=0.002\right)$, time $\left(F_{[1,264]}=\right.$ 21.29, $P \leq 0.001)$, and time $^{2}\left(F_{[1,264]}=14.17, P \leq\right.$ 0.001 ) effects, indicating that overall numbers of the three prey differed significantly. The significant time $\times$ species $\left(F_{[2,264]}=18.29, P \leq 0.001\right)$ and time ${ }^{2} \times$ species $\left(F_{[1,264]}=11.74, P \leq 0.001\right)$ interactions indicated that the rate at which prey species numbers changed also differed significantly. This was primarily due to the substantial increase in mice numbers (Figure 2). Furthermore, the significant time $\times$ habitat $\times$ species $\left(F_{[12,264]}=4.51, P \leq 0.001\right)$ and time ${ }^{2} \times$ habitat $\times$ species $\left(F_{[12,264]}=4.84, P \leq 0.001\right)$ interactions indicated that the differential rates in changes of numbers of species also changed among the different habitats. For example, the highest abundances of mice and voles occurred in November 1994 in the habitats Oak Woods I and Tallgrass Prairie I, respectively. The highest Sylvilagus abundance was documented in October 1994 in the Oldfield, with nearly equally high numbers recorded in July 1994 in the two prairie sites, probably following the weaning period of young rabbits in northern Illinois (Hoffmeister 1989). These abundance peaks are reflected in the quadratic function of the change in prey numbers over time.

\section{Among-habitat Coyote visitation rates}

Scent station visitation rates fluctuated widely among habitats and over time; no signs of Coyotes were found in Oak Woods II and the majority of tracks were recorded in the grassland habitats (Figure 3). Overall, the multiple regression of Coyote scent station visitation rates across Fermilab with the three main prey (Figure 4) and the three habitat structure variables (Figure 5) was significant $\left(R^{2}=0.241, F_{[6,98]}=4.40\right.$, $P=0.003$; Table 1). The unexplained variance in the model may be attributed to the observed variation in Coyote visitation (Figure 3) and 0 values recorded for prey abundances. Based upon results of the multiple regression, we conducted a separate analysis to discern whether the visitation rates in grasslands by Coyotes was due to prey (Microtus) or avoidance of wooded areas, from which voles were absent. Regression of scent station visitation rates with vole abundance, excluding data from the two oak woods, was not significant $\left(r^{2}=0.050, F_{[1,73]}=3.75, P=0.057\right)$.

In comparing Coyote visitation in the two adjacent habitats, Tallgrass Prairie I and Oak Woods I, scent station visitation rates, when averaged over the study period, were over three times greater in the prairie $(0.035 \pm 0.011$ (mean \pm SE ); range $0.000-0.0645)$, than the woods $(0.008, \pm 0.003$, range $0.000-0.0179$; $\left.t_{[28]}=2.486, P=0.026\right)$. However, mice abundance was two times greater in the oak woods (4.7 individuals per transect \pm 1.4 , range $0.0-19.3$ ) than the prairie (2.3 individuals per transect \pm 0.6 , range $0.3-8.0 ; t_{[28]}=1.637, P=0.113$ ).

\section{Within-habitat Coyote visitation rates}

The fire in Tallgrass Prairie I did not result in a substantial increase in prey (Figure 2). However, the perturbation in Oak Woods I was followed by a considerable increase in mice abundance, enabling a within-habitat comparison to Coyote activity. Despite the high prey abundance, Coyote visitation rates were not significantly related to mice abundance $\left(r^{2}=0.158\right.$, $\left.F_{[1,13]}=1.03, P=0.389\right)$ in Oak Woods I.

Food supplementation in Tallgrass Prairie II resulted in an approximately three-fold increase in numbers of mice compared to the non-supplemented plots by February 1995 (Figure 6). Numbers subsequently declined until densities converged on the supplemented and non-supplemented plots in May 1995. Coyotes responded to the peak in mice densities with mean visitation around the food supplemented plots over five times greater than on non-supplemented plots in February 1995 (Figure 6). Coyote visitation around these plots in the ensuing three months reflected the trend in prey availability. The result was a significant food effect $\left(F_{[1,2]}=25.60, P=0.037\right)$, a significant time effect $\left(F_{[3,6]}=9.79, P=0.013\right)$, and a significant 

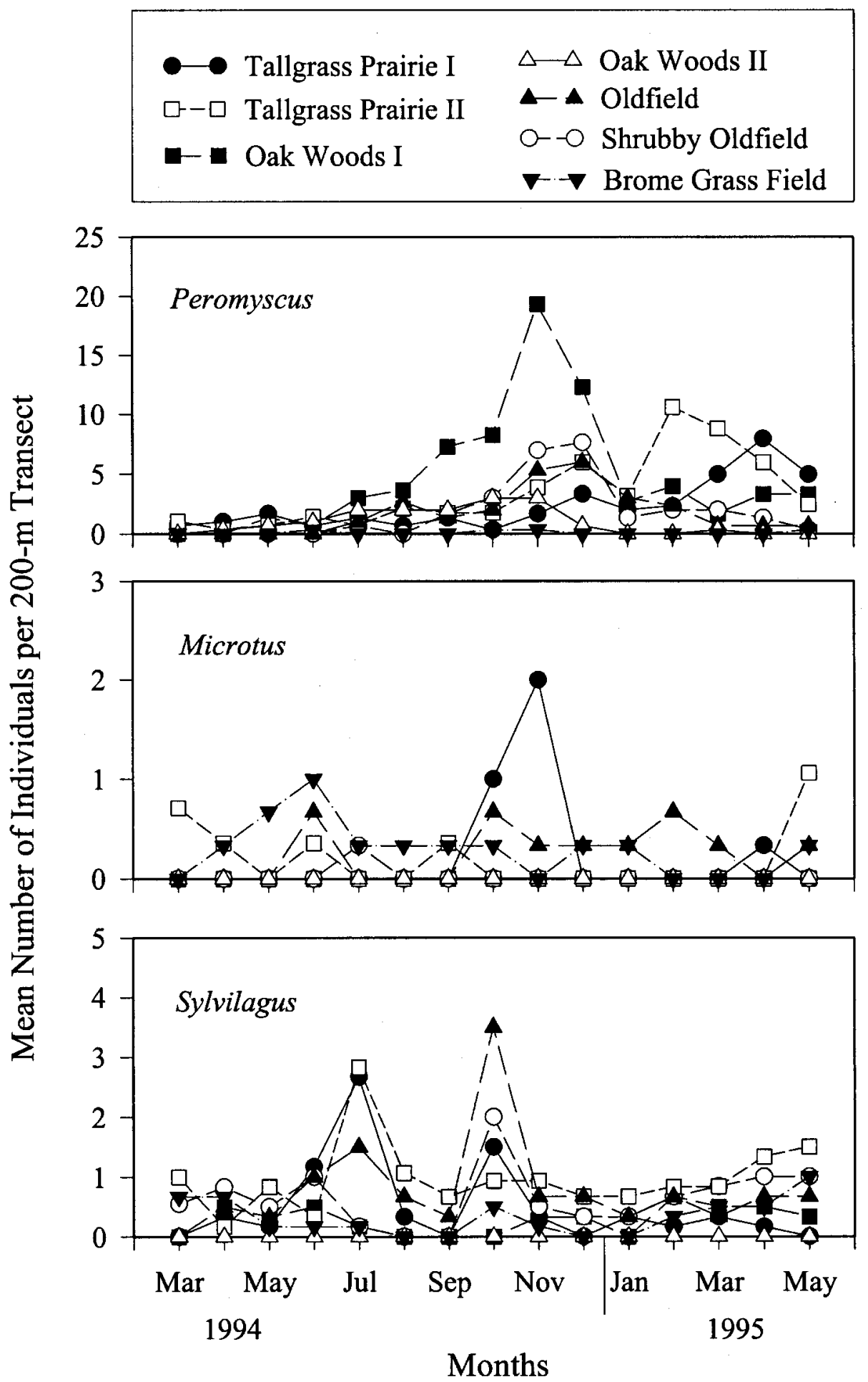

FIGURE 2. Abundances of the three main prey, Peromyscus, Microtus, and Sylvilagus, in each of the seven habitats over time. 


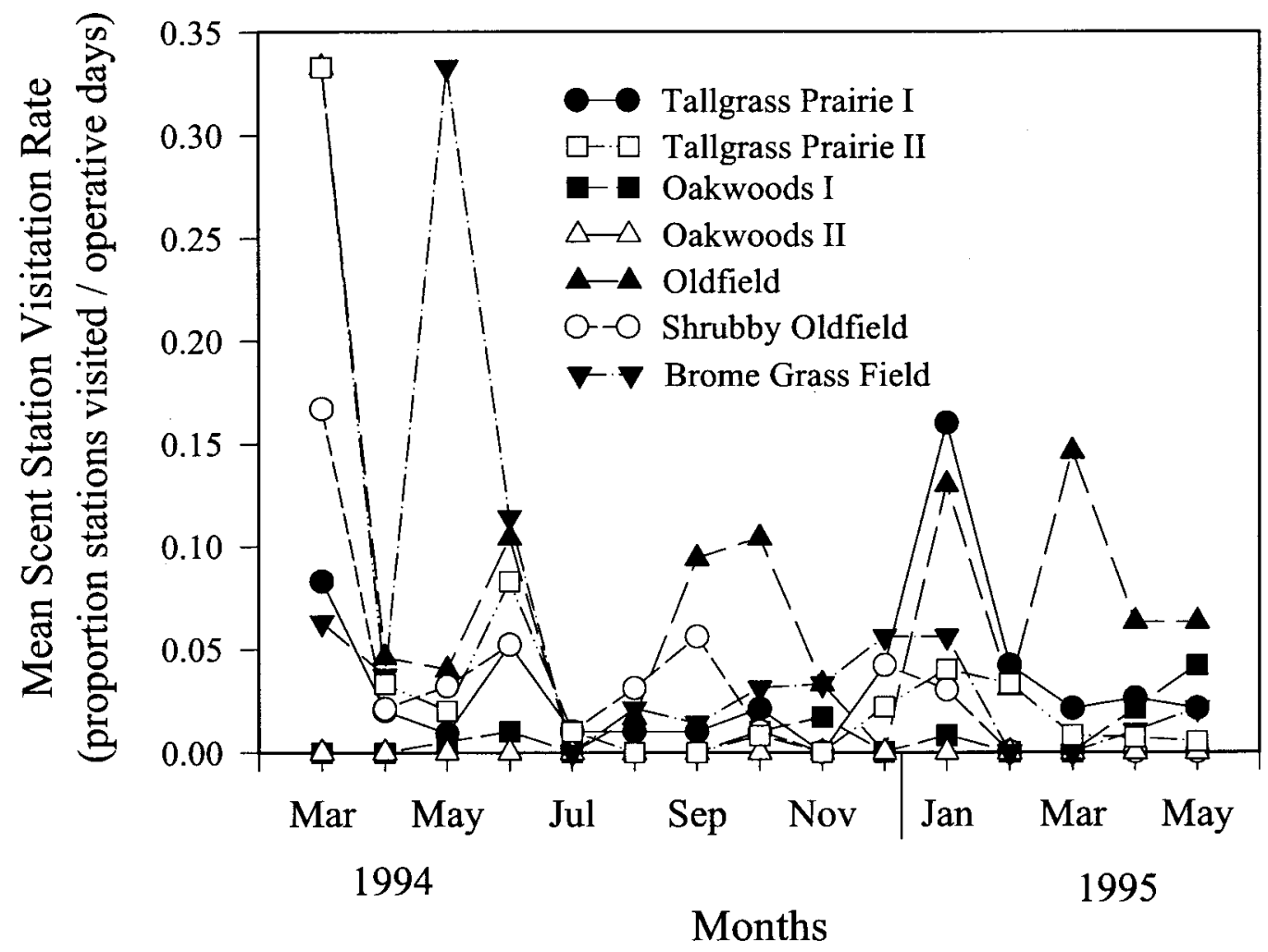

FIGURE 3. Habitat visitation of Coyotes, based upon monthly average scent station visitation rates, over time among the seven habitats.

visitation $\times$ time interaction $\left(F_{[3,6]}=10.32, P=0.012\right)$. Vegetation characteristics of habitats

Of the three vegetation metrics collected, percent ground cover and canopy cover estimates were fairly consistent between the non-growing and growing seasons for each of the seven habitats sampled (Table 2). Vertical foliage density was greater in the growing season than the non-growing season for all habitats, reflecting the increase in above-ground plant biomass. Tallgrass Prairie I had the greatest difference in ground cover and foliage density between these seasons. This was due to the almost complete absence of litter and standing vegetation during the March survey, except for small clumps of tall grasses, a result of the previous fall's fire. There were similar trends of vegetation metrics among similar habitats. Vertical foliage density was greatest in the prairies compared to other habitats during the growing season, but was relatively low for the woods. The habitats dominated by grasses, the prairies and brome grass field, exhibited $>97 \%$ ground cover, exceeding estimates of other habitats. Canopy cover, as expected, was highest in the woods, with Oakwoods II having a denser overstory than Oakwoods I. The presence of canopy in the brome grass field was attributed to a few isolated trees located near the middle of the field, which was not expansive enough to markedly influence Coyote visitation.

\section{Discussion}

Coyote habitat visitation, measured through scent station visitation rates, fluctuated greatly over time, showing no clear temporal pattern among habitats. However, overall visitation indicated an extensive use of grasslands and avoidance of woodlands. Throughout the duration of the study, there was no evidence of Coyote tracks or scat in Oak Woods II, a mature woodlot with few gaps in its overstory, even though its entire western side bordered a tallgrass prairie, a habitat where Coyote scat and tracks in snow were observed. Oak Woods I also experienced relatively little Coyote visitation during most of the study. Although scent station transects were $50 \mathrm{~m}$ from habitat edges, all Coyote tracks were observed at the western end of the transects, which were closest to a grassy area near the woods. The shrubby oldfield experienced slightly more visitation, overall, than the woods, but tracks were found primarily at scent stations within open grassy areas and in the western por- 

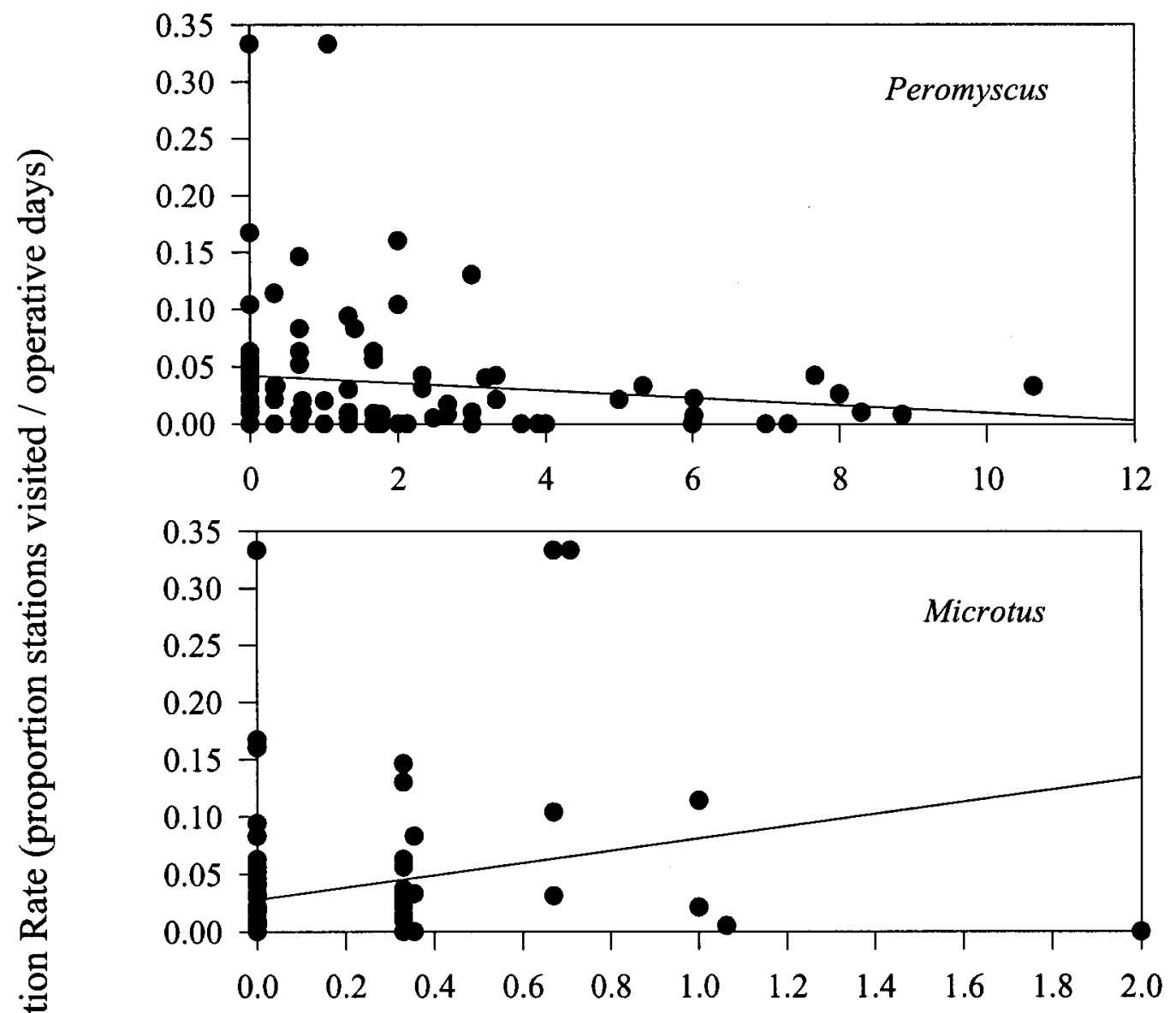

章

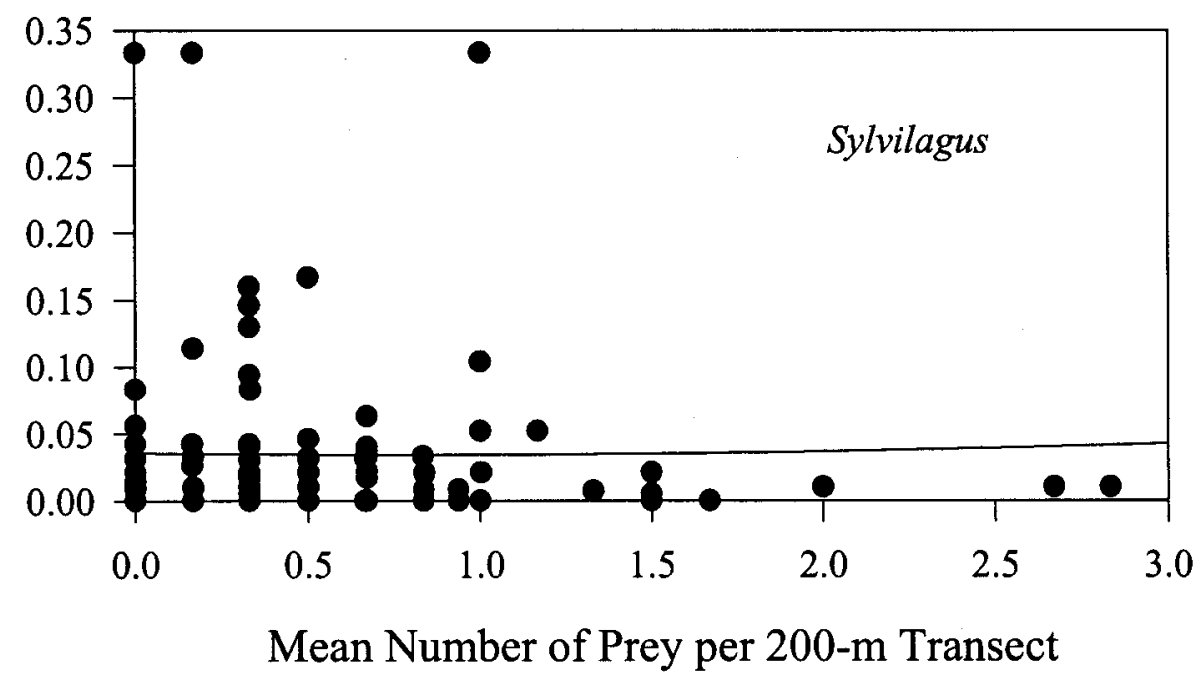

FIGURE 4. Partial regression plots for activity of Coyotes vs. abundances of each of the three main prey species. Each point represents a single observation recorded during 1 of 15 months in one of the seven habitats. 

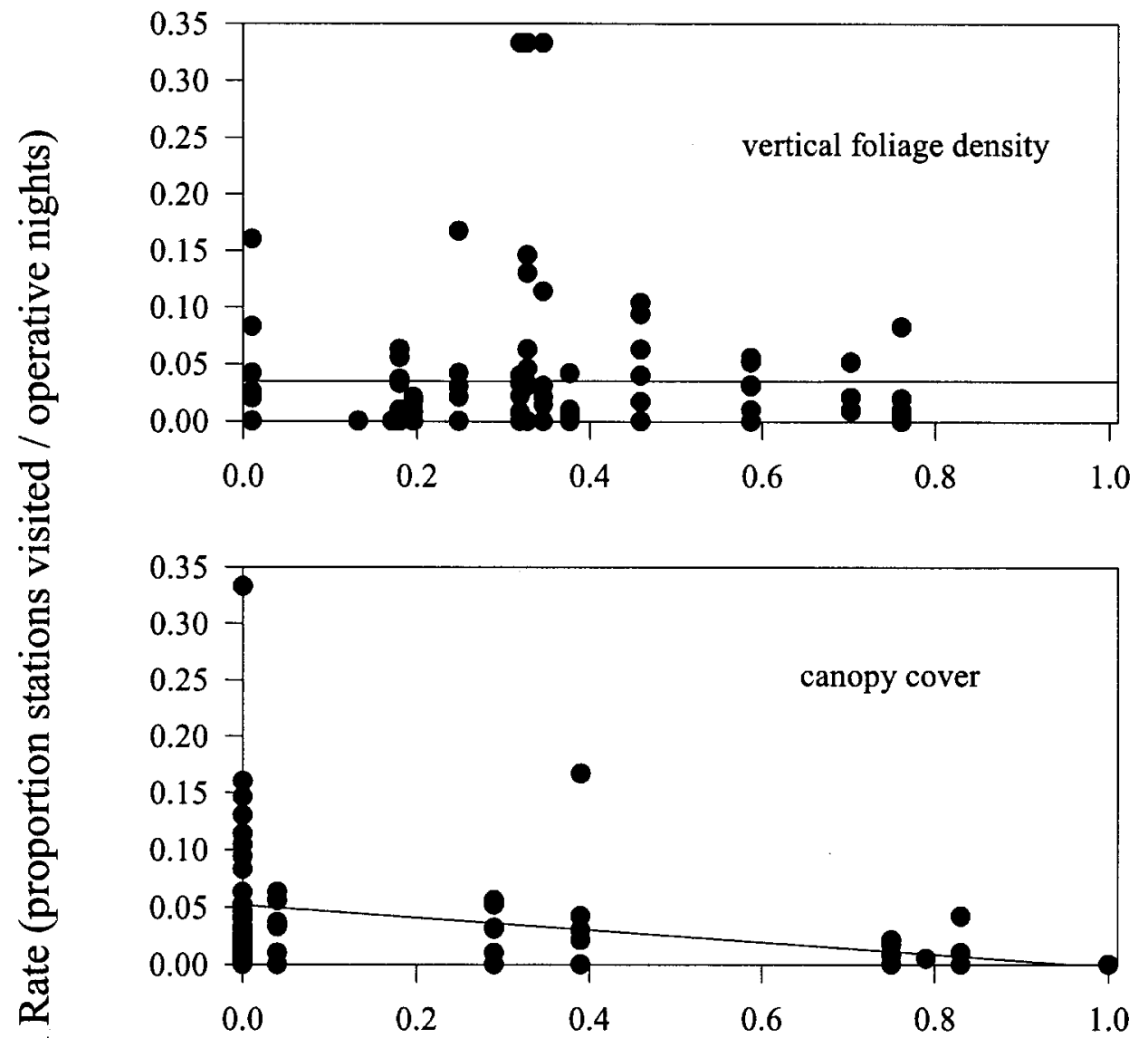

泀

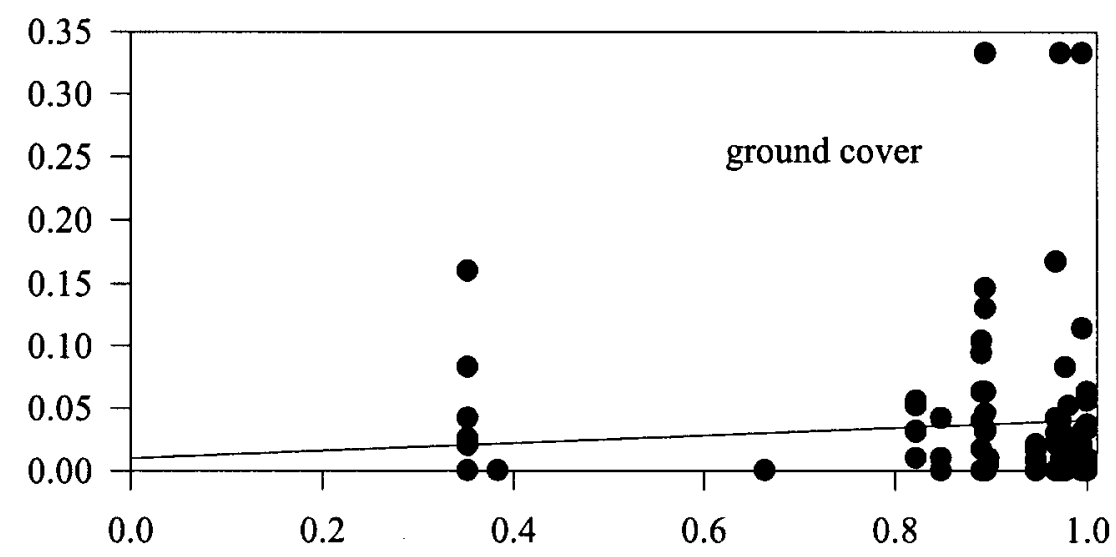

Means of Vegetation Variables 


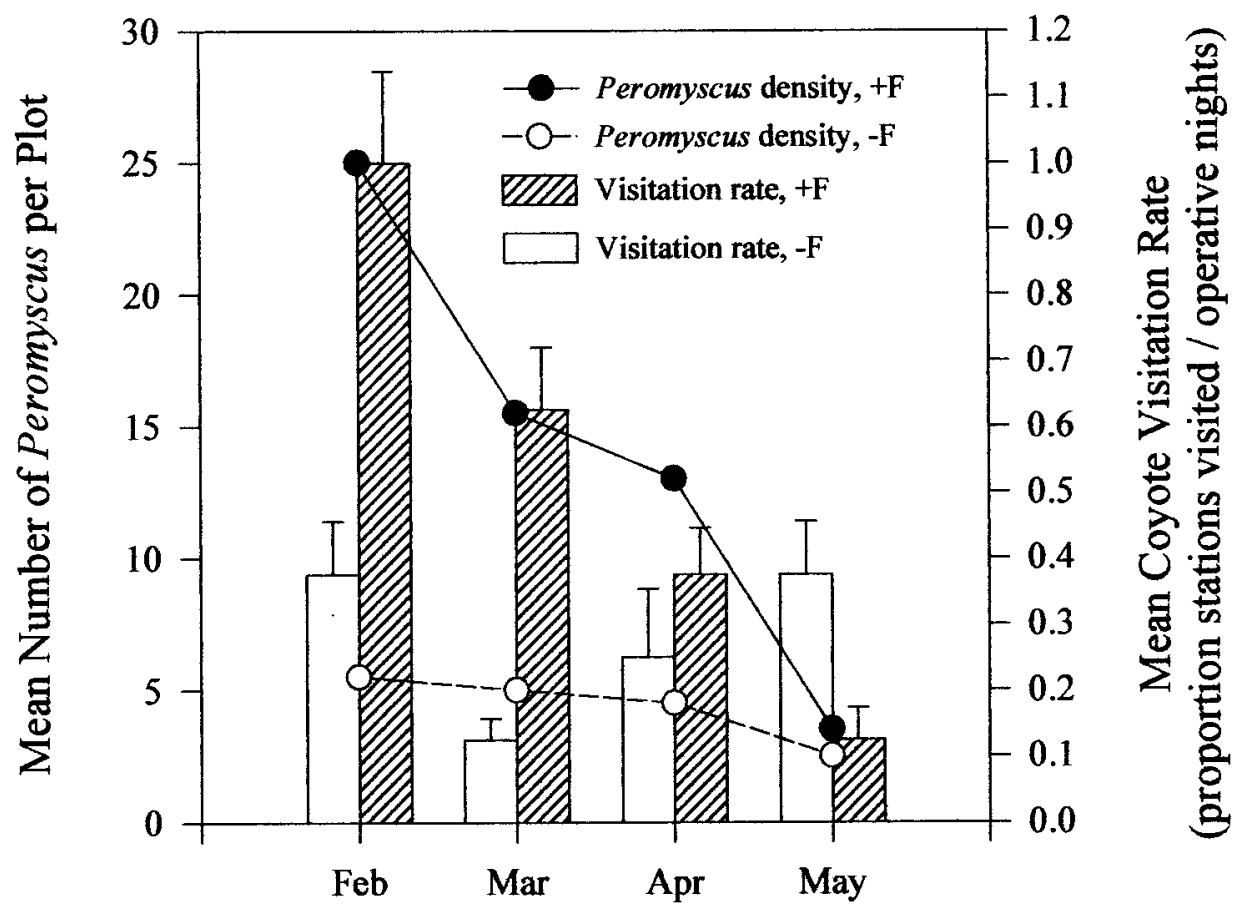

Months

FIGURE 6. Comparison of activity of Coyotes and abundance of mice on food-supplemented (+F) and non-supplemented (-F) plots in Tallgrass Prairie II.

tion of this habitat which bordered a tallgrass prairie. These observations were supported by the significant negative relationship of canopy cover to Coyote visitation rates in the multiple regression analysis. Hence, Coyotes may move a limited distance into woods but tend to avoid core areas of heavily wooded habitats. This behavior was corroborated by a two-year radio telemetry study of Coyotes in northeastern Illinois (Roth et al. 1999*).

The multiple regression analysis also indicated scent station visitation rates by Coyotes were affected by abundance of voles, which was not found in the oak woods studied. However, a simple regression of Coy-

TABLE 1. Parameter estimates for independent variables used in the multiple regression analysis of Fermilab Coyote activities.

\begin{tabular}{lccc}
\hline \hline Variable & df & $\begin{array}{c}\text { Regression } \\
\text { coefficient }\end{array}$ & $P$ \\
\hline Intercept & 1 & 0.0261 & 0.040 \\
Peromyscus & 1 & -0.0082 & 0.192 \\
Microtus & 1 & 0.1192 & 0.006 \\
Sylvilagus & 1 & -0.0169 & 0.359 \\
Foliage Density & 1 & -0.0441 & 0.295 \\
Canopy Cover & 1 & -0.0632 & 0.004 \\
Ground Cover & 1 & 0.0082 & 0.871 \\
\hline \hline
\end{tabular}

ote visitation rates on vole abundance, excluding data from the two woods, did not reveal a significant relationship. Thus, it appeared that factors other than prey, such as vegetation structure, strongly influenced Coyote habitat visitation at Fermilab. In addition, overall visitation rates were not related to the abundance of Eastern Cottontails, which comprised the greatest biomass of prey in the Coyote diets (Randa 1996). This could possibly be attributed to the association of cottontail rabbits along habitat edges (Althoff et al. 1997; Mankin and Warner 1999; Smith and Livaitis 2000). Although some of the scent station transects were located within habitat areas where rabbits were found, Coyotes could have spent more time foraging for rabbits along these edges where transects were not located.

The selective use or visitation of grasslands by the Coyotes in this investigation may be associated with their historical range. Prior to European settlement, Coyotes occupied the southwest and central plains of the U. S. including grassland of southern Canada. Clearing of forests and extermination of the Grey Wolf (Canis lupus) facilitated the north- and eastward expansion of Coyotes. Coyotes moved northward along the Great Lakes, and colonized the northeastern U.S. 
TABLE 2. Summary of vegetation characteristics for the seven different habitats sampled twice during 1995 at Fermilab; NG = non-growing season sampling, $\mathrm{G}=$ growing season sampling.

\begin{tabular}{|c|c|c|c|c|c|c|}
\hline \multirow[b]{2}{*}{ Habitat } & \multicolumn{2}{|c|}{$\begin{array}{c}\text { Mean Vertical } \\
\text { Foliage Density }\end{array}$} & \multicolumn{2}{|c|}{$\begin{array}{l}\text { Mean Percent } \\
\text { Ground Cover }\end{array}$} & \multicolumn{2}{|c|}{$\begin{array}{l}\text { Mean Canopy } \\
\text { Cover }^{\mathrm{b}}\end{array}$} \\
\hline & $\overline{\mathrm{NG}}$ & G & NG & $\mathrm{G}$ & NG & G \\
\hline Tallgrass Prairie I & 0.031 & 0.703 & 35.2 & 98.0 & 0.000 & 0.000 \\
\hline Tallgrass Prairie II & 0.320 & 0.761 & 97.2 & 97.5 & 0.000 & 0.000 \\
\hline Oakwoods I & 0.196 & 0.377 & 94.7 & 89.7 & 0.750 & 0.792 \\
\hline Oakwoods II & 0.132 & 0.172 & 66.4 & 52.4 & 1.000 & 1.000 \\
\hline Oldfield & 0.328 & 0.459 & 89.4 & 89.2 & 0.000 & 0.000 \\
\hline Shrubby Oldfield & 0.248 & 0.587 & 96.7 & 89.5 & 0.389 & 0.340 \\
\hline Brome Grass Field & 0.180 & 0.346 & 100.0 & 99.7 & 0.042 & 0.021 \\
\hline
\end{tabular}

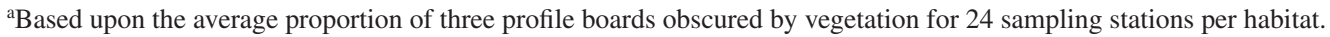

${ }^{\mathrm{b}}$ Based upon presence/absence scores (1/0 respectively) for 24 sampling stations per habitat.

(Richens and Hugie 1974) and the Midwest (Moore and Parker 1992) by the 1940s. Most Coyotes still inhabit deserts and grasslands, and those in regions with forests tend to use open, non-forested areas in a greater proportion than available (Todd et al. 1981; Toweill and Anthony 1988; Cypher 1991; Holzman et al. 1992; Murray et al. 1994; Kamler and Gipson 2000). Tracks of Coyotes observed in the snow at our study site indicated that grasslands, such as the brome grass field and tallgrass prairie, were occasionally traversed by Coyote tracks following a relatively straight path, reflecting non-foraging behavior. Hence, these open areas may not only serve as preferential foraging sites but as areas facilitating movement between habitats. A preferential use of grasslands may explain why chipmunks and tree squirrels, which were moderately common in the woodlands, were rarely detected in Coyote diets (Randa 1996).

Selective use of grasslands may have restricted the ability of Coyotes to respond spatially and temporally to localized patches of abundant prey within a habitat. In Fall 1994, when mice densities in Oak Woods I were more than twice the prey abundances at any other location, Coyote visitation did not increase significantly in that habitat. This discrepancy of prey abundance and coyote response in woodland corresponds with findings in southeastern Quebec (Richer et al. 2002). However, Coyotes demonstrated an ability to closely track prey within a grassland (Tallgrass Prairie II) as their visitation rates were correlated with experimentally manipulated abundant patches of mice. The high level and subsequent decline in Coyote visitation rates detected on scent stations around foodmanipulated plots paralleled the change in mice densities. Hence, once mice decreased following a peak in densities on these plots, Coyote visitation rates likewise diminished. It was unlikely that Coyotes were responding to a novel item in the environment (such as the odor of the food) because supplementation had been initiated four months prior to the scent station monitoring. Because voles were not detected in this habitat during the experiment, a similar test of withinhabitat Coyote response to abundant patches of this commonly consumed prey was not feasible. Yet, as with mice, Coyotes could have responded to isolated patches of voles within habitats throughout Fermilab, given that voles were still a major component of Coyote diets despite their low availability.

One limitation of the scent station transects was the difficulty in identifying Coyote responses to possible small, isolated patches of prey. Also, due to the large areas over which Coyotes may move, there was not sufficient separation to avoid visitation by the same individual between scent station transects (Diefenbach et al. 1994; Roughton and Sweeny 1982). However, by intensively sampling each habitat, these transects were effective in discerning overall trends (i.e., amonghabitat comparisons) in Coyote visitation rates and relative habitat use; they were not intended to indicate finer-scale or localized responses (e.g., patch-level foraging) within the study site.

The results we obtained from both the experimental plots and scent station transects demonstrated that Coyotes exhibit variable responses to prey availability, depending upon habitat type. Reacting relatively quickly to a local increase in prey, as seen around the experimental plots in prairie, would enhance Coyote foraging efficiency. However, preferential use of open areas, as suggested by the transect data, may constrain foraging efficiency during periods of very low prey densities when alternative prey in woodlands is under-utilized. Hence, supporting Coyote populations near urbanized areas, as in northern Illinois, requires open land expanses such as grasslands to facilitate movements across large spatial extents within the landscape and to provide an adequate prey base.

\section{Acknowledgments}

P. L. Meserve lent support and guidance throughout the course of this investigation. S. Scheiner and C. von Ende provided statistical advice. D. Cooper shared in much of the field activity. J. Mendelson, E. Miller, 
C. Petersen, B. Satterfield, and several anonymous reviewers provided helpful comments on earlier drafts of this manuscript. R. Walton oversaw Fermilab activities associated with this project and helped obtain funding. The National Environmental Research Park of the U.S. Department of Energy (MO-RS023), and the Department of Biological Sciences, Northern Illinois University provided funding for this study.

\section{Documents Cited (marked $*$ in text)}

Roth, C., E. Miller, and J. Yunger. 1999. Habitat utilization by Coyotes in northeastern Illinois when compared at landscape and local scales. $79^{\text {th }}$ Annual Meeting of the American Society of Mammalogists, University of Washington, Seattle, Washington, U.S.A. June 1999.

\section{Literature Cited}

Althoff, D. P., G. L. Storm, and D. R. Dewalle. 1997. Daytime habitat selection by cottontails in central Pennsylvania. Journal of Wildlife Management 61: 450459.

Andelt, W. F., and P. S. Gipson. 1979. Home range, activity, and daily movements of coyotes. Journal of Wildlife Management 43: 944-955.

Andelt, W. F., J. G. Kie, F. F. Knowlton, and K. Cardwell. 1987. Variation in coyote diets associated with season and successional changes in vegetation. Journal of Wildlife Management 51: 273-277.

Anthony, R. G., L. J. Niles, and J. D. Spring. 1981. Smallmammal associations in forested and old-field habitatsa quantitative comparison. Ecology 62: 955-963.

Bekoff, M. Editor. 1978. Coyotes: biology, behavior, and management. Academic Press, New York, USA. 384 pages.

Box, G. E. P., W. G. Hunter, and J. S. Hunter. 1978. Statistics for experimenters, and introduction, to design, data analysis, and model building. John Wiley and Sons, New York, USA. 672 pages.

Brillhart, D. E., and D. W. Kaufman. 1995. Spatial and seasonal variation in prey use by coyotes in north-central Kansas. Southwestern Naturalist 40: 160-166.

Brower, J., J. Zar, and C. von Ende. 1990. Field and laboratory methods for general ecology. Wm. C. Brown Publishers, Dubuque, Iowa, USA. 194 pages.

Clark, J. D., J. E. Dunn, and K. G. Smith. 1993. A multivariate model of female black bear habitat use for a geographic information system. Journal of Wildlife Management 57: 519-526.

Cook, S. F. 1959. The effects of fire on a population of small rodents. Ecology 40: 102-108.

Cypher, B. L. 1991. Coyote foraging dynamics, space use, and activity relative to resource variation at Crab Orchard National Wildlife Refuge, Illinois. Ph.D. dissertation, Southern Illinois University, Carbondale, USA. 165 pages.

DeJong, J. 1995. Habitat use and species richness of bats in a patchy landscape. Acta Theriologica 40: 237-248.

Diefenbach, D. R., M. J. Conroy, R. J. Warren, W. E. James, L. A. Baker, and T. Hon. 1994. A test of the scentstation survey technique for bobcats. Journal of Wildlife Management 58: 10-17.
Dunk, J. R., and R. J. Cooper. 1994. Territory-size regulation in Black-shouldered Kites. The Auk 111: 588595.

Hamlin, K. L., S. J. Riley, D. Pyrah, A. R. Dood, and R. J. Mackie. 1984. Relationships among mule deer fawn mortality, coyotes, and alternate prey during summer. Journal of Wildlife Management 48: 489-499.

Hoffmeister, D. F. 1989. Mammals of Illinois. University of Illinois Press, Chicago, USA. 348 pages.

Holzman, S., M. J. Conroy, and J. Pickering. 1992. Home range, movements, and habitat use of coyotes in southcentral Georgia. Journal of Wildlife Management 56: 139-146.

Jaksic, F. M., P. L. Meserve, J. R. Gutierrez, and E. Tabilo. 1993. Predation on small mammals in a Chilean semiarid scrub. Revista Chilena de Historia Natural 66: 305-321.

James, F. C., and H. H. Shugart, Jr. 1970. A quantitative method of habitat description. Audubon Field Notes 24: 727-736.

Kamler, J. F., and P. S. Gipson. 2000. Space and habitat use by resident and transient coyotes. Canadian Journal of Zoology 78: 2106-2111.

Kaufman, G. A., D. W. Kaufman, and E. J. Finck. 1983. Effects of fire on rodents in tallgrass prairie of the Flint Hills region of eastern Kansas. Prairie Naturalist 15: 4956.

Kaufman, G. A., D. W. Kaufman, and E. J. Finck. 1988. Influence of fire and topography on habitat selection by Peromyscus maniculatus and Reithrodontomys magalotis in ungrazed tallgrass prairie. Journal of Mammalogy 69: 342-352.

Korpimäki, E. 1994. Rapid or delayed tracking of multiannual vole cycles by avian predators? Journal of Animal Ecology 63: 619-628.

Korschgen, L. J., and H. B. Stuart. 1972. Twenty years of avian predator-small mammal relationships in Missouri. Journal of Wildlife Management 36: 269-282.

Lamberson, R. H., B. R. Noon, C. Voss, and K. S. McKelvey. 1994. Reserve design for territorial species-the effects of patch size and spacing on the viability of the Northern Spotted Owl. Conservation Biology 8: 185195.

Le Boulengé, E. 1987. Package C. M. R.: analysis of capture-recapture data. Université Catholique de Louvain, Croix du Sud, Belgium.

Littell, R. C., R. J. Freud, and P. C. Spector. 1991. SAS system for linear models. SAS Institute Incorporated, Cary, North Carolina, USA. 329 pages.

MacArthur, R. H., and J. W. MacArthur. 1961. On bird species diversity. Ecology 42: 594-598.

Mankin, P. C., and R. E. Warner. 1999. Response of eastern cottontails to intensive row-crop farming. Journal of Mammalogy 80: 940-949.

Moore, G. C., and G. R. Parker. 1992. Colonization by the eastern coyote (Canis latrans). Pages 21-22 in Ecology and management of the eastern coyote. Edited by A. H. Boer. Wildlife Research Unit, University of New Brunswick, Fredericton, Canada.

Murray, D. L., S. Boutin, and M. O'Donoghue. 1994. Winter habitat selection by lynx and coyotes in relation to snowshoe hare abundance. Canadian Journal of Zoology 72: 1444-1451. 
Ostfeld, R. S., C. G. Jones, and J. O. Wolff. 1996. Of mice and mast: ecological connections in eastern deciduous forests. BioScience 46: 323-330.

Person, D. K., and H. H. Hirth. 1991. Home range and habitat use of coyotes in a farm region of Vermont. Journal of Wildlife Management 55: 433-441.

Randa, L. A. 1996. Prey selectivity and foraging activity of Canis latrans and Vulpes vulpes in response to prey fluctuations and habitat in a heterogeneous landscape. M.S. thesis, Northern Illinois University, DeKalb, USA. 80 pages.

Richens, V. B., and R. D. Hugie. 1974. Distribution, taxonomic status, and characteristics of coyotes in Maine. Journal of Wildlife Management 38: 447-454.

Richer, M., M. Crête, and J. Ouellet. 2002. The low performance of forest versus rural coyotes in northeastern North America: inequality between presence and availability of prey. Ecoscience 9: 44-54.

Roughton, R. D., and M. W. Sweeny. 1982. Refinements in scent station methodology for assessing trends in carnivore populations. Journal of Wildlife Management 46: 217-229.

SAS Institute, Inc. 1990. SAS/STAT User's Guide, Version 6, Fourth Edition, Volume 2, Cary, North Carolina, USA.

Shivik, J. A., and R. L. Crabtree. 1995. Coyote activity levels in relation to presence of California Gulls at Mono Lake, California. California Fish and Game 81: 22-28.
Smallwood, K. S. 1995. Scaling Swainson's Hawk population density for assessing habitat use across an agricultural landscape. Journal of Raptor Research 29: 172-178.

Smith, D. F., and J. A. Livaitis. 2000. Foraging strategies of sympatric lagomorphs: implications for differential success in fragmented landscapes. Canadian Journal of Zoology 78: 2134-2141.

Todd, A. W., L. B. Keith, and C. A. Fischer. 1981. Population ecology of coyotes during a fluctuation of snowshoe hares. Journal of Wildlife Management 45: 629-640.

Toweill, D. E. and R. G. Anthony. 1988. Coyote foods in a coniferous forest in Oregon. Journal of Wildlife Management 52: 507-512.

Wolff, J. O. 1996. Population fluctuations of mast-eating rodents are correlated with acorn production. Journal of Mammalogy 77: 850-856.

Woolf, A., D. R. Shoemaker, and M. Cooper. 1993. Evidence of tularemia regulating a semi-isolated cottontail rabbit population. Journal of Wildlife Management 57: 144-157.

Yunger, J. A. 2002. Response of two low-density populations of Peromyscus leucopus to increased food availability: a natural and a manipulative experiment. Journal of Mammalogy 83: 267-279.

Received 27 February 2003

Accepted 14 October 2004 